\title{
IbM SOPIR MOBIL RENTAL TOMOHON
}

\author{
Rinny Suryani Rorimpandey \\ Universitas Negeri Manado
}

\begin{abstract}
ABSTRAK
Pariwisata merupakan salah satu sektor pembangunan yang saat ini sedang digalakkan oleh pemerintah. Tomohon memiliki berbagai potensi pariwisata diantaranya objek wisata alam dan objek wisata budaya serta beragam atraksi. Wisatawan asing yang berkunjung ke Tomohon adalah tamu yang harus dilayani dengan baik. Untuk itu masyarakat harus dapat berkomunikasi dengan menggunakan Bahasa Inggris dengan para wisatawan, agar wisatawan merasa senang di Tomohon. Namun masih banyak sopir mobil rental yang tidak dapat mampu bahasa Inggris, padahal mereka yang bersentuhan langsung dengan para wisawtan asing, yang mereka lakukan ketika melayani dengan wisman hanya menggunakan bahasa tubuh atau menggunakan penerjemah. Untuk itu perlu diadakan pelatihan untuk meningkatkan kemampuan bebahasa Inggris, baik dari: speaking, listening, reading, writng dan vocabulary bagi sopir mobil rental agar dapat mereka melayani dengan jasa kendaraan mereka serta memperkenalkan dan mempromosikan potensi wisata Kota Tomohon beserta industri pendukungnya, dan meningkatkan kesejahteraan masyarakat. Metode yang diterapkan ialah memberikan materi pelatihan dengan metode ceramah, diskusi, tanya jawab, conversation, reading, retell. Kegiatan pelatihan bagi sopir mobil rental akan dilaksanakan selama 2 bulan. Materi Bahasa Inggris yang berikan: berbagai conversation, vocabulary, reading text, alat tulis dan buku. Materi yang diberikan meliputi : introduction, greeting, dealing with numbers (addres, time, date)giving direction, vocabulary; verb, noun and adjective, asking for information, getting information, , and cross culture undertanding. Dalam DIPA Program Kemitraan Masyarakat yang didanai oleh UNIMA adapun luaran yang dihasilkan dalam bentuk Artikel atau Jurnal :PKM Sopir Mobil Rental Tomohon.Pada pelatihan ini juga menghasilkan modul pelatihan yang dicetak dalam bentuk buku saku yang dibagikan kepada seluruh peserta. Walaupun masih dalam bentuk sederhana, dengan revisi dan pengembangan seperlunya modul ini bermanfaat bagipelatihan pelatihan selanjutnya, yang setingkat atau tingkat lanjutannya.
\end{abstract}




\section{PENDAHULUAN}

Pariwisata merupakan salah satu sektor pembangunan yang saat ini sedang digalakkan oleh pemerintah. Hal ini disebabkan pariwisata mempunyai peran yang sangat penting dalam pembangunan Indonesia khususnya sebagai penghasil devisa negara di samping sektor migas. Tujuan pengembangan pariwisata di Indonesia terlihat dengan jelas dalam Instruksi Presiden Republik Indonesia Nomor 9 Tahun 1969, khususnya Bab II Pasal 3, yang menyebutkan "Usaha-usaha pengembangan pariwisata di Indonesia bersifat suatu pengembangan "industri pariwisata" dan merupakan bagian dari usaha pengembangan dan pembangunan serta kesejahteraan masyarakat dan Negara" (Yoeti, 1996: 151). Berdasarkan Instruksi Presiden tersebut, dikatakan bahwa tujuan pengembangan pariwisata di Indonesia adalah untuk meningkatkan pendapatan devisa pada khususnya dan pendapatan negara dan masyarakat pada umumnya, perluasan kesempatan serta lapangan kerja, dan mendorong kegiatan-kegiatan industri penunjang dan industri-industri sampingan lainnya. Serta memperkenalkan dan mendayagunakan keindahan alam dan kebudayaan Indonesia. Selain itu juga meningkatkan persaudaraan/persahabatan nasional dan internasional dan saat ini masing-masing propinsi dan kabupaten/kota mulai giat membenahi dan memajukan sektor pariwisata yang dimilikinya.

Kota Tomohon kini menjadi primadona di Sulawesi Utara. Pastinya, kota dijadikan sebagai destinasi traveling. Meskipun hanya memiliki luas sekitar 147, $21 \mathrm{~km} 2$ namun Tomohon memiliki beberapa tempat wisata menarik yang telah dikenal hingga ke luar negeri. Berkunjung ke Manado, Sulawesi Utara tidak akan lengkap rasanya jika tidak menikmati keindahan alam di Kota Tomohon. Seperti beberapa tempat wisata menarik di Kota Tomohon seperti: Danau Linauw atau yang lebih dikenal dengan Danau Linow, Bukit Doa Tomohon, Air Terjun Pinaras, Gunung Mahawu, Hutan Pinus, Vihara Ekayana, eko wisata desa Rurukan, hamparan kebun bunga, dan populer pasar Tomohon, pasar ekstrim di Sulawesi Utara. Banyak turist yang suka suka dengan dunia fotografi datang ke Kota Tomohon ingin mengabadikan keindahan alam di Sulawesi Utara.Hamparan kebun bunga berlatar belakang gunung lokon, matahari terbit yang indah dari puncak mahawu merupakan momen yang sulit untuk tidak diabadikan melalui rekaman kamera. Selain itu, ada beberapa acara menarik yang dilaksanakan di Kota Tomohon dan menyedot perhatian para wisatawan seperti Festival Bunga Internasional dan Pawai 17-an.

Sejak tahun 2008 Kementerian Pariwisata dan Ekonomi Kreatif bekerjasama dengan berbagai pihak menggelar acara bertajuk Tomohon International Flower Festival (TIFF). Pada awal diselenggarakan pada tahun 2008 acara ini hanya memenuhi skala nasional saja, selanjutnya pada tahun 2010 acara ini dikembangkan dengan skala yang lebih luas dengan taraf internasional. Kementerian Pariwisata dan Ekonomi Kreatif pun memasukkan festival ini ke dalam calendar of event Kementerian Pariwisata dan Ekonomi Kreatif. Dan dalam rangka mendukung program "Wonderful Indonesia" menuju peningkatan ekonomi melalui peningkatan arus kunjungan wisatawan, baik mancanegara maupun Nusantara, dan untuk mempromosikan berbagai potensi yang ada.

Untuk menghadapi situasi seperti ini salah satu aspek yang paling krusial adalah masyarakat harus mampu berkomunikasi dengan menggunakan Bahasa Inggris sebagai bahasa internasional dengan para wisatawan, agar mereka merasa betah dan senang di Tomohon ini. Karena dengan penguasaan bahasa Inggris yang baik dari masyarakat dapat

- Memperkenalkan dan mempromosikan potensi wisata Kota Bunga Tomohon beserta industri pendukungnya pada Wisman

- Mendukung program Pemerintah Pusat dalam menyukseskan Wonderful Indonesia;

- Meningkatkan kesejahteraan masyarakat melalui tumbuhnya usaha pariwisata

- Meningkatkan kunjungan Wisatawan baik Mancanegara maupun Nusantara Karena dapat memberikan dampak positif bagi peningkatan kesejahteraan masyarakat lokal.

Saat pemerintah kota Tomohon menyelenggarakan event-event yang berskala nasional dan internasional, Kota ini semakin ramai dikunjungi oleh turis domestik, objek-objek wisata pun tak luput dari turis manca negara. Sebagian turis manca negara biasanya mereka memanfaatkan jasa sewa mobil untuk menemani perjalanan berwisata mereka. Disinilah pentingnya kemampuan berbahasa Inggris bagi para sopir mobil rental. Dengan bahasa Inggris, para sopir akan dapat berkomunikasi dengan para turis asing dari luar negeri. Sehingga potensi salah paham antara sopir dan turis asing tidak terjadi. Oleh sebab itu Sebagai daerah yang mengedepankan sektor jasa, maka memang sumberdaya yang ada harus dilatih dan dipersiapkan secara matang agar 
mampu menjawab tantangan yang ada dibidang pariwisata. Para sopir harus diberdayakan secara maksimal dari segi bahasa dan juga etika. Sangat penting bagi sopir untuk menguasai Bahasa Inggris percakapan sehari-hari dan yang berhubungan dengan pekerjaan mereka agar dapat mendukung program pemerintah dan meningkatkan pendapatan. Karena itu perlu dilaksanakan pelatihan bagi para sopir, yang memberi jasa angkutan kepada wisatawan, mereka harus dibimbing melalui pelatihan bahasa sebagai alat komunikasi. Sebagai alat komunikasi, berarti para sopir haruslah diajari tentang struktur bahasa Inggris yang benar serta bagaimana bahasa Inggris itu digunakan dengan memperhatikan fakta - fakta luar bahasa, situasi, dengan siapa berbicara, makna berbicara dan sebagainya.

\section{Permasalahan Mitra}

Bahasa inggris di Indonesia merupakan satu dari bahasa asing yang telah diajarkan di sekolah - sekolah mulai dari tingkat Sekolah Dasar bahkan perguruan tinggi. Di Perguruan Tinggi ada Program studi Bahasa Inggris ini telah banyak mencetak lulusan - lulusan yang berkompeten dalam berbahasa inggris. Yang sangat ironis adalah megahnya bangunan, indahnya kehidupan di bawah laut dengan flora dan fauna yang khas dan bervariasi itu tidak dibarengi dengan peningkatan kualitas SDM sebagai pelaku industri jasa pariwisata. Para sopir sewa mobil belum diberdayakan untuk menjadi pelaku jasa pariwisata tersebut. Pada umumnya mereka belum dapat berkomunikasi dengan bahasa asing terutama bahasa inggris dengan baik.

Pemerintah dan Masyarakat Tomohon untuk semakin mempersiapkan diri agar mampu untuk dapat berkompetisi di era globalisasi disamping itu pula menjadi tuan rumah yang baik dalam rangka mengembangakan potensi pariwisata yang ada di kota Tomohon. salah satu tuntutan yang penting adalah harus memberi pelayanan yang terbaik. Hal ini juga berlaku bagi penyedia jasa, khusus mobil sewa atau rental. Betapa banyak penyedia jasa mobil sewa bangkrut karena pelayanan mereka berikan pada user dirasa kurang memuaskan, termasuk pelayan sopirnya. Ketidakmampuan para sopir rental berkomunikasi dengan user/wisman dapat menyebabkan sopir tidak dapat memahami apa yang mereka maksud sehingga terjadi kesalahpahaman, bahkan karena kurangnya pengetahuan dalam bahasa Inggris sehingga sulit bagi mereka untuk mengerti tulisan berbahasa Inggris di beberapa tempat wisata atau tempat tertentu di kota Tomohon.
Padahal Ada banyak event nasional bahkan internasional yang diadakan oleh pemerintah kota Tomohon, yang menyedot banyak wisatawan berkunjung ke kota ini untuk menyaksikan event tersebut bahkan mengunjungi tempat pariwisata yang menjadi daya tarik dan membuat penasaran para wisatawan dan ingin melihat lebih dekat dan ingin mengetahui keindahan Tomohon yang harus menggunakan kendaraan. Dan pada saat terjadi komunikasi antara wisatawan asing dengan para sopir rental, mereka bertanya tentang tempat yang akan di kunjungi, berapa biaya untuk ke tempat destinasi, berapa lama atau mereka akan bertanya tentang hal-hal yang menyangkut keberadaan kota Tomohon. Tapi para sopir ini hanya malu-malu, tersipu-sipu bahkan bersikap pura-pura tidak mendengar atau tidak memperhatikan apa yang bicarakan para wisatawan padanya. Ini disebabkan mereka tidak mengerti apa yang di tanyakan oleh para wisatawan, bahkan tak jarang terjadi kesalah pahaman dan sering para sopir lari tidak mau melayani para turis tersebut sehingga banyak wisatawan yang bingung bahkan mengurung niat mereka. Kalau ada guide yang memandu hal ini tidak jadi masalah. Namun ada juga para sopir yang terpaksa melayani para wisatawan dengan memakai Bahasa simbol ala Tarzan dengan cara mengerahkan seluruh Bahasa tubuh untuk dipahami oleh lawan bicara. Tetapi apabila sopir rental mobil -Tomohon dapat menggunakan bahasa Inggris dengan baik ini merupakan hal positif dan akan berkesan luar biasa bagi para wisatawan yang datang, memudahkan komunikasi juga menambah keakraban mereka dengan sopir walaupun dengan Bahasa yang sangat sederhana.

Selain ketidak mampuan Bahasa Inggris, (dalam berbicara:speaking, mendengar; listening, membaca; reading menulis: writing, kosakata; vocabulary) oleh para sopir taxi kurang mengenenal budaya dari berbagai negara asing, baik budaya yang menyertai Bahasa, maupun yang lainnya, sehingga tidak dapat memahami komunikasi yang terjalin sehingga dapat menimbulkan kesalahpahaman yang berefek terjadinya sesuatu yang tidak baik.

Jadi masalah yang dihadapi oleh para sopir mobil rental Tomohon adalah

- Ketidak mampuan dalam berbahasa inggris baik dari cara mengucapkan/speaking, mendengar/listening, membaca/reading, menulis/writing, Tidak memiliki atau kurangnya kosakata/vocabulary sehingga tidak dapat berkomunikasi dalam Bahasa Inggris 
- Tidak memahami latarbelakang budaya para wisatawan

- Tidak memiliki referensi ( buku - buku ) berkaitan dengan percakapan sehari - hari meskipun di toko - toko buku telah di jual berbagai referensi percakapan dari bahasa inggris.

- Tidak dapat meningkatkan pendepatan

- Sehingga tidak mampu menujang program pemerintah.

Bertolak dari permasalahan diatas perlu dilakukan tindakan agar sopir mobil rental dapat memiliki pengetahuan dasar tentang bahasa Inggris yang dapat digunakannya untuk berkomunikasi dengan wisatawan. Tindakan ini dilakukan oleh pihak yang berkompetensi dalam hal ini perguruan tinggi sebagai pelaksana PKM. Kami dari Universitas Negeri Manado melaksanakan pengabdian merupakan IPTEKS bagi Masyarakat khususnya para sopir mobil rental agar mereka dapat meningkatkan kemampuan berbahasa Inggris dengan baik dalam rangka menyukseskan program pemerintah.

Marthon (1999:18) menyatakan bahwa mengembangkan kepedulian dan kemampuan mengamati kebutuhan dunia di sekitar kita merupakan fungsi utama perguruan tinggi dalam bidang penelitian dan pengabdian.

Melihat bahwa permasalahan diatas adalah kompleks dan dilihat bahwa tidak semua permasalahan itu dapat diselesaikan dalam kurun waktu tertentu maka berdasarkan justifikasi dan kesempatan bersama para sopir mobil rental sebagai mitra dalam pelatihan bahasa Inggris. Kami dari Universitas negeri Manado melaksanakan pengabdian menerapkan Ipteks bagi masyarakat khususnya para sopir mobil rental agar dapat meningkatkan kemampuan berbahasa Inggris sehingga masyarakat dapat berpartisipasi dan menyukseskan program pemerintah serta dapat memasarkan produk pula meningkatkan kesejahteraan.

\section{METODE}

Adapun metode yang diterapkan ialah memberikan materi pelatihan dengan metode ceramah, diskusi, tanya jawab, conversation, reading, retell. Kita ketahui bahwa pelatihan masyarakat merupakan pendidikan non formal, dengan demikian sifatnya berbeda dengan pendidikan formal yang dilaksanakan disekolah. Dalam pelatihan non formal bagi orang dewasa, ada karakteristik peserta pelatihan/ orang dewasa yang harus diperhatikan yakni:

- Orang dewasa mempunyai pengalaman, dan pengalaman masing-masing orang berbeda.

- Lebih suka menerima saran-saran daripada digurui.

- Biasanya meneliai dirinya lebih rendah daripada kemampuan sebenarnya yang ada pada dirinya.

- Biasanya lebih menyenangi hal-hal yang praktis.

- Biasanya membutuhkan waktu belajar yang relative lama + , membutuhkan suasana akrab dan menjalin hubungan yang erat.

- Lebih suka dihargai daripada disalahkan.

- Hanya mau belajar dengan baik jika mereka mengganggapnya perlu bagi mereka.

- Lebih memperhatikan hal-hal yang menarik bagi dia dan menjadi kebutuhannya.

- Menyukai cara belajar yang melibatkan peran mereka.

Dan pendekatan yang digunakan pendekatan sosial yang merupakan pendekatan terhadap masyarakat sasaran, para sopir mobil rental. Prinsipnya ialah bahwa sopir mobil rental sasaran harus dijadikan subjek dan bukan objek dari kegiatan pengabdian pada masyarakat ini. Untuk itu para sopir harus sebanyak mungkin dilibatkan dalam kegiatan ini, termasuk dalam proses perencanaan.

\section{Tahap kegiatan}

\section{Persiapan}

Tahap persiapan pelatihan diartikan sebagai tahap perencanaan yang rinci dan spesifik yang dimulai dari kegiatan Penyusunan organisasi pelaksanaan pelatihan sampai dengan persiapan pelaksanaan pembukaan pelatihan.-

- Tahap pertama dilakukan analisis kebutuhan masalah yang dihadapi oleh para sopir mobil rental dan merumuskan masalah sehingga dapat dicari solusi pemecahan. Dari hasil kegiatan analisis kebutuhan menunjukan bahwa : kemampuan berbahasa Inggris sangat dibutuhkan sopir mobil rental menghadapi kunjungan wisatawan, kebanyakan para sopir mobil rental tidak mampu berbahasa Inggris.

- Sebelum pelatihan dimulai penyelenggara harus mengumpulkan data dan informasi untuk menentukan siapa peserta pelatihan dan menyiapkan pendaftaran calon peserta. Kegiatan termasuk dalam persiapan tenaga fasilitator/instruktur meliputi kurikulum dan silabus. 
- Selanjutnya persiapan sarana Pelatihan, kegiatan ini termasuk penyiapan tempat pelatihan, pembuatan jadwal, , persiapan materi / penyusunan buku panduan pelatihan bahasa Inggris bagi sopir mobil rental menghadapi kunjungan wisatawan. Modul Bahasa Inggris yang berisikan : berbagai conversation, vocabulary, reading text, Materi yang diberikan meliputi : introduction, greeting, dealing with numbers (addres, time, date)giving direction, buying flower, asking for information, getting information, name of the flowers, and cross culture undertanding penyiapan alat bantu pengajaran, penyiapan alat tulis untuk pelatihan..

- Dan juga kegiatan persiapan untuk pembukaan meliputi pembuatan undangan pembukaan pelatihan, penyiapan laporan penyelenggara pelatihan, penyiapan tempat untuk acara pembukaan. Persiapan pembukaan pelatihan sudah selesai minimal 2 hari sebelum acara pembukaan pelatihan dilaksanakan

\section{Tahap Pelaksanaan}

Pada pelatihan yang dilaksanakan dalam suasa belajar dan berlangsung dalam beberapa hari. Dalam kegiatan pembelajaran diawali dengan pengenalan fasiltator/instrukur, dilanjutkan dengan pemberian materi. Metode pembelajaran yang digunakan adalah metode cerama, diskusi, retell. Pada pembelajaran yang komplek ini mencakup :

Speaking : atau berbicara adalah menyatakan bahwa komunikatif adalah pertukaran antara orang-orang, pengetahuan, informasi, ide, pendapat, perasaan sehingga menjadi sebuah gagasan dari apa yang mereka katakana. Mungkin para sopir mobil rental mengalami kesulitan dalam speaking/ berbicara dalam bahasa inggris karena dalam speaking harus terampil dalam menggunakan kosakata dan tata cara menggunakannya- dalam bagian ini para sopir mobil rental mengucapkan kata-kata yang diucapkan instruktur secara berulang-ulang. Setelah mereka sudah dapat mengucapkan katakata tersebut instruktur memberi dialog, awalnya instruktur membaca dialog tersebut kemudian diikuti oleh para peserta. Setelah itu instruktur memberi kesempatan untuk para peserta membaca sendiri, kemudian membagi, kelompok, dan perorangan untuk membaca dialog tersebut. Apabila mereka sudah mampu mereka diminta untuk menghafal dialog itu. Setelah menghafal mereka akan membuat conversation sesuai yang telah mereka pelajari. Disamping itu diajari bahwa dalam berkomunikasi harus ada kepercayaan diri dengan harus memiliki banyak latihan agar bahasa inggris mereka baik. Setiap hari para peserta harus membuat conversation dengan topik yang diberikan dan di hari berikut dengan pasangan akan mempresentasikannya. Di sini mereka dilatih pula cara bertanya dan menjawab dengan baik.

Reading; adalah membaca teks atau beberapa bagian bacaan dalam bacaan. Dalam kegiatan membaca ini para peserta membaca sebuah teks untuk memperoleh ilmu/pengetahuan. Tujuan kegiatan membaca adalah untuk membaca teks bahasa inggris yang pendek. Dalam membaca peserta harus membaca keras untuk melihat apakah setiap kata yang dibacakan sudah dilafalkan dengan baik. Kalau masih adalah yang melafalkan salah maka instruktruktur segera memperbaiki. Setiap minggu mereka diberi tugas membaca teks yang sudah diberikan dan harus menerjemahkannya ke dalam bahasa Indonesia dan di hari berikutnya mereka menceritakan kembali apa yang suda mereka baca dalam bahasa inggris tanpa menggunakan teks.

Writing adalah menulis dalam bahasa inggris, dalam kegiatan pelatihan ini peserta dilatih untuk, mencoba menulis sebuah kegiatan, dengan menggunakan ide, gagasan dan perasan mereka sendiri dengan menggunakan kamus yang diberikan bagi mereka. Para peserta ajar cara menulis surat setelah itu mereka diminta untuk menuliskan surat dengan menggunakan ide mereka sendiri.

Listening adalah kegiatan mendengarkan/memperhatikan baik-baik apa yang mereka dengar di tape recorder, ataupun yang dibaca atau diucapkan seseorang dan mereka harus pahami sehingga mereka dapat menjelaskan atau menceritakan kembali apa yang sudah mereka dengar baik melalui speaking atau writing. Mereka harus pula mengetahui arti dan makna dari apa yang mereka dengar. Setiap ada listening mereka ditugaskan mendengar apa yang mereka dengan dari audio kemudian mereka menceritakannya kembali apa yang suda didengar dalam bahasa inggris.

Vocabulary. Memiliki kosa-kata/vocabulary yang banyak adalah satu hal yang penting agar dapat berkomunikasi dalam bahasa inggris. Jadi vocabulary adalah kumpulan daftar kata bahasa inggris yang sudah kuasai. Jadi ketika melihat dan mendengar kata itu sudah tahu maknanya. Dan dituntut setiap hari para peserta harus mampu menghafal 7 kata bahasa inggris dengan artinya karena semakin meningkat vocabulary pemahaman akan bacaan, tulisan atau ucapan bahasa inggris akan semakin mudah. 
Dan Pelatihan ini akan dilaksanakan selama dua bulan setiap minggu dua kali pertemuan, tiap pertemuan 2 x 60 menit, setiap hari Senin dan Rabu pada pukul 16.00-18.00.

\section{Pasca Pelaksanaan Program}

* Evaluasi

Tujuan dari pelaksanaan evaluasi adalah;

- Mengetahui tingkat kemampuan berbicara, membaca, menulis dan mendengar dari peserta.

- Mengetahui kemampuan penguasaan kosa kata sehingga mampu berkominikasi dalam Bahasa Inggris

* Penyusunan Laporan

* Laporan disusun setelah semua program telah selesai dilaksanakan.

\section{HASIL DAN PEMBAHASAN}

Kegiatan PKM ini mampu mengakomodasi peserta yang lebih besar dari rencana semula (direncanakan 20 orang yang mengikuti 29 orang). Selama kegiatan pengabdian pada masyarakat ini berlangsung terlihat betapa besar apresiasi para peserta pelatihan. Hal ini terbukti dengan kehadiran dan partisipasi sopir mobil rental sepanjang pelatihan berlangsung. Para sopir mobil rental menyadari benar pentingnya pelatihan bahasa Inggris untuk mereka, terutama dalam menghadapi para wisatawan asing yang berkunjung ke Tomohon dan menawarkan jasa anggkutan mereka. Dan dengan pelatihan ini mereka mendapat pengetahuan serta bekal dalam meningkatkan kemampuan berkomunikasi dalam bahasa Inggris.

Pelatihan ini dilaksanakan dalam kurun waktu 3 bulan, dari bulan Maret sampai Juni. Pertemuan siadakan dua kali ppertemuan dalam seminggu dengan waktu $2 \times 50$ menit. Partisipasi peserta cukup baik, usia tidak menjadi kendala bagi para peserta ]. Misalnya peserta usia diatas 40 tahun tidak segan-segan bermain simulasi memerankan sopir dan penumpang dalam praktik penggunaan bahasa.

Materi atau topik yang diberikan dalam pelatihan ini meliputi bahan peningkatan tentang kebahasaan dan ketrampilan dalam berbahasa Inggris. Mengingat kegiatan pelatihan bertujuan untuk meningkatkan pengetahuan dan ketrampilan berbahasa Inggris.
Materi atau topik pelatihan ini menampilkan contoh-contoh penggunaan kata-kata, frase-frase dan kalimat-kalimat yang sering digunakan dalam keseharian kegiatan daripada sopir mobil rental. Diberikan pula situasi-situasi yang tepat dimana kata-kata, frase-frase dan kalimatkalimat itu digunakan. Penyajian contohcontoh situasi tersebut adalah penting supaya para pengguna bahasa dapat memahami dan mampu membedakan ungkapan untuk situasi formal maupun non formal. Lebi dari itu, faktor budaya juga dikemukakan dalam penggunaan ungkapan- ungkapan yang disajikan.

Materi yang diberikan meliputi:

1. Introduction Ungkapan-ungkapan yang digunakan untuk memperkenalkan diri ataupun memperkenalkan orang lain.

2. Greeting Ungkapan yang digunakan untuk memberi salam dan merespon, bila bertemu dengan orang lain.

3. Dealing with Numbers

Ungkapan yang berhubungan dengan angka atau bilangan, harga, nomor telephone dan alamat.

4. Giving Direction

Ungkapan yang digunakan dalam menanyakan serta memberitahukan atau menunjukan tempat/alamat.

5. Vocabulary, Verb, Noun and adjective Kata verba, kata benda dan adjektiva.

6. Asking for information Ungkapan yang digunakan untuk menanyakan dan memberikan informasi.

7. Getting information

Ungkapan yang digunakan untun mendapatkan dan memperoleh informasi.

8. Cross Culure Understanding

Diberi pelatihan mengenai budaya dari berbagai negara asing, baik budaya yang menyertai bahasa, maupun yang lainnya juga wajib diketahui untuk menjaga supaya bisa memahami semua komunikasi yang terjalin dengan wisatawan asing tanpa terjadi kesalahpahaman yang berarti. Hal tersebut meliputi stereotype, kesukaan, 
hal-hal yang tidak disukai, sesuatu tang tabu dan hal-hal lainnya terutama budaya yang berbeda dengan budaya Indonesia. Sebab ketidak tahuan budaya asing terutama saat berkomunikasi bisa mengakibatkan kesalapahaman yang berefek terjadinya sesuatu yang tidak baik.

Dari hasil evaluasi terhadap 29 peserta ada 10 orang yang mendapat dari sangat baik dan 19 adalah baik. Evaluasi awal dan akhir pelatihan dilaksanakan dengan Tanya jawab dan bermain peran. Tanya jawab dilakukan untuk mengukur pemahaman umum peserta terhadap pembicaraan dengan orang lain dan kemampuan memberi respon, dan bermain dimaksudkan untuk mengukur kemampuan menggunakan ungkapan-ungkapan dalam berkomunikasi dengan tamu atau pengguna jasa yang berbahasa Inggris. Peserta memperoleh skor yang lebih tinggi apabila dalam bermain peran dapat mengembangkan dialog sampai diluar yang tertera di dalam modul pembelajaran.

Pada pelatihan ini juga menghasilkan modul pelatihan yang dicetak dalam bentuk buku saku yang dibagikan kepada seluruh peserta. Walaupun masih dalam bentuk sederhana, dengan revisi dan pengembangan seperlunya modul ini bermanfaat bagipelatihan pelatihan selanjutnya, yang setingkat atau tingkat lanjutannya Dalam DIPA Program Kemitraan Masyarakat yang didanai oleh UNIMA adapun luaran yang dihasilkan dalam bentuk Artikel atau Jurnal: PKM Sopir Mobil Rental Tomohon.

\section{KESIMPULAN}

Pelaksanaan kegiatan pelatihan bahasa Inggris bagi sopir mobil rental Tomohon telah memberikan manfaat yang besar bagi setiap peserta. Melalui pelatihan ini para peserta telah memiliki cukup kosakata dalam bahasa Inggris sehingga mereka telah dapat berkomunikasi dalam bahasa Inggris untuk kegiatan-kegiatan setiap hari, seperti menyapa seseorang, berkomunikasi dengan tamu atau pengguna jasa, serta mengetahui sebagian budaya, sopan santun dalam melayani tamu mancanegara.

\section{DAFTAR PUSTAKA}

Cahyono, Bambang Y. The Teaching of English Language Skills and English Language Components, Malang: State University of Malang Press.2010

Ferrer-Hanreddy, Jami \& Whalley, Elizabeth. A Listening/Speaking Skills Book: With Learning Strategies and Language Functions, Singapore: McGraw-Hill Companies, Inc. 1996

Silberman, Mel. Active Learning: 101 Strategi Pembelajaran Aktif, Yogyakarta: Pustaka Insan Madani. 2009.

Tillit Bruce \& Bruder Mary N. Speaking Naturally - Communication Skills In American English, Cambridge : Cambrige University Press. 